\title{
PERPUSTAKAAN MASJID: UPAYA MEMBANGUN KESADARAN INKLUSIF
}

\author{
Hariyah \\ Perpustakaan Badan Litbang dan Diklat Kementerian Agama RI \\ Korespondensi: hariyahalkhanza@yahoo.com
}

\begin{abstract}
The main focus of this paper is to elaborate social inclusion in the mosque library. This paper is a qualitative descriptive approach that intends to know the history and understanding of the mosque library, the role of what is being done mosque libraries, and describes the shape of social inclusion in the mosque library. The conclusion that the mosque library is part of an effort to build awareness of inclusion and empower the community to become more mature in religion and society. This empowerment among others with facilitation, education, and accommodation needs of people of all religious communities without discriminating user community in terms of religion, creed, class, physical and so on, the mosque library is the embodiment of democracy and the means to the community well informed. Mosque Libraries should be able to accommodate the information needs of users, into an open space for social activities, and become lifelong education.
\end{abstract}

\begin{abstract}
ABSTRAK
Fokus utama dari makalah ini adalah mengelaborasi inklusi sosial pada perpustakaan masjid.Tulisan ini bersifat kualitatif dengan pendekatan deskriptif yang bermaksud untuk mengetahui sejarah dan pengertian perpustakaan masjid,peran apa saja yang dilakukan perpustakaan masjid, dan menggambarkan bentuk inklusi sosial pada perpustakaan masjid. Disimpulkan bahwa perpustakaan masjid merupakan bagian dari upaya membangun kesadaran inklusi dan melakukan pemberdayaan masyarakat untuk semakin dewasa dalam beragama dan bermasyarakat. Pemberdayaan ini antara lain dilakukan dengan fasilitasi, edukasi, dan akomodasi kebutuhan-kebutuhan masyarakat umat beragama, dengan tanpa membeda-bedakan masyarakat penggunanya dari segi agama, keyakinan, golongan, fisik dan sebagainya. Perpustakaan masjid merupakan perwujudan demokrasi dan sarana menuju masyarakat well informed. Perpustakaan masjid harus mampu mengakomodir kebutuhan informasi penggunanya, menjadi ruang terbuka bagi aktivitas sosial kemasyarakatan, dan menjadi media pembelajaran sepanjang hayat.
\end{abstract}

Keywords: Social inclusion; Etnoreligious conflict; Mosque library

\section{PENDAHULUAN}

Geografis bangsa Indonesia sangat majemuk baik secara multikultural maupun multi-relijius. Kemajemukan tersebut apabila dapat dikelola secara baik, merupakan modal sosial yang amat berharga bagi pembangunan bangsa. Sebaliknya, jika tidak dapat dikelola secara baik, kemajemukan berpotensi menimbulkan konflik dan dis-harmoni sosial.Dalam hal ini, segenap elemen bangsa sangat diharapkan untuk terus menerus melakukan upaya pengelolaan kehidupan bermasyarakat dan pemeliharaan kerukunan hidup beragama.

Indonesia pernah dihadapkan pada maraknya aksi terorisme atas nama agama terutama Islam. Hal ini telah membuat umat Islam sebagai pihak yang dipersalahkan. Lembaga-lembaga pendidikan Islam di Indonesia, seperti madrasah atau pondok pesantren tidak lepas dari tuduhan yang memojokkan tersebut, bahkan masjid-pun turut mengalami hal serupa.

Tidak pernah tercatat sepanjang sejarah Islam bahwa pesantren, madrasah, dan masjid menjadi tempat berkembangnya terorisme. Beberapa literatur menyebutkan bahwa pesantren merupakan model 
pendidikan pertama dan tertua di Indonesia, kiprahnya sangat besar terhadap kemajuan bangsa Indonesia. Begitu pula masjid, dalam sejarah dikenal sebagai pusat kebudayaan peradaban Islam. Perannya tidak saja terbatas sebagai tempat ibadah, tetapi juga turut serta mencerdaskan kehidupan bangsa, baik melalui fungsi pendidikan, sosial, maupun budaya.

Hasil kajian di Badan Litbang dan Diklat Kementerian Agama oleh Ruhana (2013) menunjukkan telah berhasil menginventarisasi faktor-faktor keagamaan yang kerap berpengaruh terhadap kondisi kerukunan umat beragama di Indonesia. Hal tersebut terkait dengan penyiaran agama, bantuan keagamaan luar negeri, perkawinan antar pemeluk agama berbeda, pengangkatan anak, pendidikan agama, perayaan hari besar keagamaan, perawatan dan pemakaman jenazah, penodaan agama, kegiatan kelompok sempalan, transparansi informasi keagamaan, dan terkait pendirian rumah ibadat. Faktor non-keagamaan, seperti kesenjangan sosial-ekonomi, dan dinamika politik, juga mempengaruhi kondisi kerukunan umat beragama di Indonesia. Terkait hal tersebut, pemerintah mengeluarkan dua kebijakan, yaitu:

1) Melakukan pemberdayaan masyarakat atau umat beragama untuk semakin dewasa dalam beragama dan bermasyarakat. Dengan demikian, problem-problem antarumat beragama dapat secara mandiri ditangani dan diselesaikan diantara mereka. Pemberdayaan ini, dilakukan dengan fasilitasi, edukasi, dan akomodasi kebutuhan-kebutuhan masyarakat umat beragama.

2) Penguatan regulasi yang mengatur lalu lintas umat beragama dalam berinteraksi diantara mereka.

Hal ini dimaksudkan memberi rambu-rambu atau aturan yang disepakati bersama agar semua umat beragama tertib dan saling menghormati satu sama lain sehingga kondisi kerukunan tercapai (Ruhana, 2013).

Pemberdayaan masyarakat dengan fasilitasi edukasi dilakukan melalui pemberdayaan perpustakaan masjid. Perpustakaan masjid merupakan bagian yang dapat mewujudkan harmonisasi kehidupan umat beragama. Kehidupan harmonis umat beragama menjadi salah satu bentuk inklusi sosial, di mana masyarakat antar umat beragama dapat hidup secara damai dan saling menghargai di tengah-tengah beragamnya keyakinan masyarakat. Salah satu pendekatan yang tepat untuk dapat mewujudkan fungsi tersebut, yaitu membangun pusat literatur atau perpustakaan masjid sehingga menambah wawasan jamaah tentang pentingnya kehidupan harmonis dalam masyarakat. Dalam konteks tersebut, fungsi masjid tidak hanya sebatas pusat kegiatan ibadah, tetapi juga menjadi pusat aktivitas sosial, ekonomi, dan keilmuan bagi jamaahnya.

Berdasarkan hal tersebut, permasalahan tulisan ini adalah bagaimanakah bentuk inklusi sosial perpustakaan masjid dalam mewujudkan kehidupan harmonis dalam masyarakat, yang dilihat dari aspek sejarah, peran, dan bentuk inklusi sosial perpustakaan masjid. Adapun tujuan tulisan ini, yaitu memaparkan: 1) sejarah dan pengertian perpustakaan masjid; 2) peran perpustakaan masjid; dan 3) bentuk inklusi sosial pada perpustakaan masjid.

\section{TINJAUAN PUSTAKA}

\subsection{Sejarah Perpustakaan Islam}

Pada zaman ketika Nabi Muhammad Hijrah dari Mekkah ke Madinah, hal pertama kali yang beliau lakukan adalah membangun masjid. Masjid pada waktu itu digunakan sebagai markas besar tentara dan pusat gerakan pembebasan umat dari penghambaan kepada manusia, berhala atau taghut. Masjid digunakan sebagai pusat pendidikan yang mengajak manusia pada keutamaan, kecintaan pada pengetahuan, kesadaran sosial dan lain sebagainya (Nahlawi, 1995). 
Laugu (2006) menyebutkan bahwa pada abad ke-7 merupakan kelahiran Islam yang menimbulkan suatu perubahan menyeluruh dalam hampir semua fase kehidupan. Pengajaran agama baru ini mampu menarik perhatian besar masyarakat terhadap ilmu pengetahuan. Pengajaran ini memperjelas bahwa mendidik bukanlah hak prerogatif yang akan dilakukan oleh segelintir orang saja, tetapi menjadi tanggung jawab setiap individu pada suatu wilayah. Hal ini dapat dilihat dalam masa awal kenabian Muhammad SAW, yaitu dalam wahyu pertama yang diturunkan kepadanya adalah perintah untuk membaca. Kemudian disebutkan bahwa sejumlah perpustakaan masjid dimulai sebagai maktabah, khazain al-maktabah, atau perpustakaan Al Qur'an. Kebiasaan umum yang terdapat dalam masyarakat Islam bahwa koleksi-koleksi Al Qur'an telah disajikan di berbagai masjid. Contohnya, pada perpustakaan masjid Qairawan di Tunisia telah berkembang dengan hadiah kitab-kitab yang besar atau koleksi-koleksi Al Qur'an, dan buku-buku lainnya di serahkan ke masjid oleh ilmuwan kota dan keluarga-keluarga yang terkenal.

Laugu (2006) menyebutkan bahwa masjid dipakai sebagai tempat untuk melaksanakan ibadah. Untuk menjalankan ibadah tersebut seorang muslim harus melalui suatu cara yang harus dipahami secara baik dan benar. Untuk mendapatkan pemahaman yang benar tersebut, harus ada suatu proses pembelajaran bisa melalui seorang guru atau ustazd dengan cara belajar mandiri melalui koleksi-koleksi Al Qur'an ataupun hadis. Perpustakaan masjid muncul untuk menyediakan sarana yang bisa mendukung proses pembelajaran tersebut sehingga pengadaan berbagai koleksi dalam masjid menjadi suatu aktivitas yang sangat penting, menjadi suatu fenomena tersendiri yang disebut sebagai perpustakaan masjid.

Masjid yang pada awalnya dianggap sebagai rumah atau perpustakaan Al Qur'an, telah berkembang sebagai tempat berbagai literatur dan khasanah pemikiran para tokoh dan masyarakatnya. Perpustakaan masjid pada akhirnya menjadi pusat informasi masyarakat Islam saat itu dan hingga saat ini. Hal ini mendasari adanya perpustakaan masjid sebagai perpustakaan Islam dan umat Islam.

\subsection{Pengertian Perpustakaan Masjid}

Menurut Undang-undang No.43 Tahun 2007 tentang Perpustakaan, disebutkan bahwa perpustakaan adalah institusi pengelola karya tulis, karya cetak, dan/atau karya rekam secara profesional dengan sistem baku, guna memenuhi kebutuhan pendidikan, penelitian, preservasi, informasi, dan rekreasi. Mengacu pengertian tersebut, perpustakaan rumah ibadah adalah lembaga atau unit kerja yang mengelola karya tulis, karya cetak, dan/atau karya rekam secara profesional dengan sistem baku, yang dibentuk dan dikembangkan oleh rumah ibadah guna memenuhi kebutuhan penelitian, pengetahuan, informasi, keagamaan, dan rekreasi. Kamarudin dkk (2014) dalam artikelnya yang berjudul Library: Roles and Issues, menyatakan "What is mosque library? as stated by Ministry of Religious Affairs, Brunei, the mosque library is a building or a space in a mosque building where it places the variety of information sources such as books, magazines, reports, and audiovisuals or else in order to be as a reference, research on muslim or non-muslim society in the particular area”. Menurut Departemen Agama Brunei Darussalam, perpustakaan masjid adalah bangunan atau ruang di sebuah bangunan masjid yang memiliki beragam sumber informasi, seperti buku, majalah, laporan, audio visual dan sebagainya sehingga menjadi referensi dan penelitian tentang masyarakat muslim atau nonmuslim di daerah tertentu.

Dapat dikatakan bahwa perpustakaan masjid terletak di masjid, memiliki beragam sumber 
informasi, serta terbuka bagi umat dan masyarakat umum disekitarnya tanpa membedakan umur, jenis kelamin, suku, ras, agama, dan status sosial-ekonomi. Perpustakaan masjid menjadi penyokong utama lembaga induknya (masjid), yang merupakan bagian integral dari kegiatan pembangunan umat Islam.

\subsection{Peran Perpustakaan Masjid}

Tujuan perpustakaan rumah ibadah seperti disebutkan Perpustakaan Nasional dalam Pedoman Umum Penyelenggaraan Rumah Ibadah bahwa secara umum perpustakaan rumah ibadah bertujuan menyediakan layanan informasi dalam rangka memenuhi kebutuhan informasi bagi jemaah dan masyarakat di lingkungan rumah ibadah, baik informasi untuk kecerdasan spiritual, intelektual, maupun kecerdasan emosional.

Keberadaan masjid sebagai pusat komunitas, masjid berfungsi untuk kegiatan masyarakat pada tiga peran dasar, yaitu sosial, politik, dan pendidikan (Laugu 2006). Tingkat prioritas pada setiap peran tersebut berbeda dari satu tempat ke tempat lainnya. Namun dalam banyak kasus, masjid menyediakan setiap kebutuhan dan keperluan masyarakatnya. Perpustakaan masjid muncul menjadi suatu bagian penting dari masjid yang berfungsi mendukung jalannya peran yang di emban oleh masjid tersebut dalam kehidupan masyarakat secara luas.

Laugu (2006) menjelaskan posisi perpustakaan masjid dalam konteks peran sosial lebih diarahkan pada penyediaan informasi untuk menunjang jalannya kegiatan sosial masyarakat. Sebagai contoh, kegiatan yang berkenaan dengan orasi, perpustakaan mencoba untuk mengumpulkan informasi tentang orasi tersebut. Para orator kemungkinan besar mendapatkan bacaan yang tersedia dalam koleksi perpustakaan masjid yang digunakan untuk menambah wawasan mereka terhadap topik yang disampaikan tersebut.

Pada kegiatan yang berkenaan dengan pengobatan, misalnya perpustakaan mempunyai fungsi mengumpulkan informasi pengobatan atau menyediakan buku-buku koleksi yang menunjang pembuatan obat-obatan untuk mengobati penyakit masyarakat. Di bidang politik, perpustakaan masjid berperan mendukung kontinuitas pengetahuan masyarakat Islam yang berkenaan dengan politik, dengan cara menyediakan koleksi tentang ilmu politik.

Selain itu, masjid memiliki citra sebagai pusat pendidikan dan peribadatan. Dua peran ini menurut Laugu (2006) terus berlanjut selama masa Umaiyah, Abbasiyah, dan periode berikutnya. Di sinilah perpustakaan masjid menjadi sangat penting dan dibutuhkan untuk menunjang jalannya aktivitas pendidikan dan pengajaran. Pengajaran dengan intensitas petemuan yang sangat terbatas, menjadikan keberadaan koleksi-koleksi perpustakaan masjid menjadi sangat signifikan dalam membantu tercapainya tujuan pendidikan yang dilaksanakan di masjid.

\subsection{Inklusi Sosial}

Inklusi atau inklusif menurut kamus Merriam-Webster adalah covering or including everything, yaitu menutupi atau meliputi segala sesuatu; open to everyone, yaitu terbuka pada setiap orang; not limited to certain people, yaitu tidak terbatas pada orang tertentu; including the stated limits and everything in between, yaitu meliputi batas-batas dan segala sesuatu yang dinyatakan diantaranya. Inklusi sosial dalam kamus Collins English Dictionary adalah "the provision of certain rights to all individuals and groups in society, such as employment, adequate housing, health care, education and training, etc", yaitu pemberian hak tertentu untuk semua individu dan kelompok dalam masyarakat, seperti pekerjaan, perumahan yang layak, pelayanan kesehatan, pendidikan dan pelatihan dan sebagainya. 
Menurut Roscommon Country Council, social inclusion is a term that can be used to describe a series of positive actions to achieve equality of access to goods and services, to assist all individuals to participate in community and society, to encourage the contribution of all persons to social and cultural life and to be aware of and to challenge all forms of discrimination. By ensuring that the marginalised and those living in poverty have greater participation in decision-making which affects their lives, will allow them to improve their standard of living and overall well-being. Inklusi sosial adalah istilah yang dapat digunakan untuk menggambarkan serangkaian tindakan positif untuk mencapai kesetaraan akses terhadap barang dan jasa, untuk membantu semua individu untuk berpartisipasi dalam komunitas dan masyarakat, untuk mendorong kontribusi semua orang untuk kehidupan sosial dan budaya, dan untuk menyadari dan menantang segala bentuk diskriminasi. Dengan memastikan bahwa mereka yang hidup dalam kemiskinan dan terpinggirkan, memiliki partisipasi yang lebih besar dalam pengambilan keputusan yang mempengaruhi kehidupan mereka akan memungkinkan mereka untuk meningkatkan standar hidup mereka dan kesejahteraan secara keseluruhan.

Sementara itu, DAKSA Foundation Blog atau Yayasan Daya Akselerasi Aditama menyebutkan bahwa inklusi digunakan sebagai sebuah pendekatan untuk membangun dan mengembangkan sebuah lingkungan yang semakin terbuka; mengajak masuk dan mengikutsertakan semua orang dengan berbagai perbedaan latar belakang, karakteristik, kemampuan, status, kondisi, etnik, budaya dan lainnya. Terbuka dalam konsep lingkungan inklusi berarti semua orang yang tinggal, berada dan beraktivitas dalam lingkungan keluarga, sekolah ataupun masyarakat merasa aman dan nyaman mendapatkan hak dan melaksanakan kewajibannya. Jadi, lingkungan inklusi adalah lingkungan sosial masyarakat yang terbuka, ramah, meniadakan hambatan dan menyenangkan karena setiap warga masyarakat tanpa terkecuali saling menghargai dan merangkul setiap perbedaan.

Pada dasarnya akses dan partisipasi pada berbagai aktivitas dalam kehidupan masyarakat merupakan hak asasi setiap orang atau setiap warga negara. Kerangka normatif bagi inklusi sosial sudah ditetapkan dalam UUD 1945. Misalnya, pada pasal 29 UUD 1945, dinyatakan: (1) Negara berdasar atas Ketuhanan Yang Maha Esa; (2) Negara menjamin kemerdekaan tiap-tiap penduduk untuk memeluk agamanya masing-masing dan untuk beribadat menurut agama dan kepercayaan itu. Kemudian pasal 31 berbunyi: (1) Setiap warga negara berhak mendapat pendidikan; (2) Setiap warga negara wajib mengikuti pendidikan dasar dan pemerintah wajib membiayainya. Sementara Pasal 34 berbunyi: (1) Fakir miskin dan anak-anak terlantar dipelihara oleh Negara; (2) Negara mengembangkan sistem jaminan sosial bagi seluruh rakyat dan memberdayakan masyarakat yang lemah dan tidak mampu sesuai dengan martabat kemanusiaan; (3) Negara bertanggung jawab atas penyediaan fasilitas pelayanan kesehatan dan fasilitas pelayanan umum yang layak.

Dalam konsep inklusi sosial, menurut penulis terdapat unsur pemberdayaan. Ife (1995) dalam Farida (2014) menyatakan empowerment is a process of helping disadvantaged groups and individual to compete more effectively with other interests, by helping them to learn and use in lobbying, using the media, engaging in political action, understanding how to work the system, and so on. Pendekatan utama dalam konsep ini bermakna bahwa masyarakat tidak dijadikan objek dari berbagai proyek pembangunan, tetapi merupakan subjek dari upaya pembangunan. Berdasarkan konsep demikian, maka pemberdayaan masyarakat harus mengikuti pendekatan:

1) Halini yang populer disebut pemihakan.Upaya pemihakan ini ditujukan langsung kepada yang memerlukan, dengan program yang dirancang untuk mengatasi masalah sesuai dengan 
kebutuhannya.

2) Mengikutsertakan atau dilaksanakan oleh masyarakat yang menjadi sasaran.Mengikutsertakan masyarakat yang akan dibantu mempunyai beberapa tujuan, yakni agar bantuan tersebut efektif karena sesuai dengan kehendak dan mengenali kemampuan serta kebutuhan mereka. Selain itu, untuk meningkatkan kemampuan masyarakat dalam merancang, melaksanakan, mengelola, dan mempertanggungjawabkan upaya peningkatan diri dan ekonominya.

3) Pendekatan kelompok. Mengingat jika dilakukan secara sendiri-sendiri, masyarakat miskin kesulitan dalam memecahkan masalah yang dihadapinya. Selain itu, lingkup bantuan menjadi terlalu luas apabila penanganannya dilakukan secara individual. Pendekatan kelompok ini paling efektif dan dilihat dari penggunaan sumber daya juga lebih efisien. Aspek penting dalam suatu program pemberdayaan masyarakat adalah program yang disusun sendiri oleh masyarakat, menjawab kebutuhan dasarmasyarakat, mendukung keterlibatan kaum miskin, perempuan, buta huruf, dan kelompok terabaikan lainnya. Di samping itu, program pemberdayaan harus dibangun dari sumber daya lokal, sensitif terhadap nilai-nilai budaya setempat, memperhatikan dampak lingkungan, tidak menciptakan ketergantungan, berbagai pihak terkait terlibat, serta berkelanjutan.

Sebuah penelitian pernah dilakukan oleh Puslitbang Pendidikan Agama dan Keagamaan (2006) yang berjudul “Studi Pelayanan Pendidikan Keagamaan pada Masyarakat Minoritas”. Penelitian ini mengambil lokasi pada 11 propinsi, yaitu Sumatera Utara, Sumatera Barat, Banten, Yogyakarta, Jawa Tengah, Jawa Timur, Kalimantan Barat, Kalimantan Tengah, Bali, Sulawesi Utara, dan Maluku. Salah satu kesimpulan penelitian menyebutkan bahwa tempat ibadah umat Islam, seperti masjid merupakan pelayanan keagamaan yang pertama dan utama. Di samping sebagai tempat ibadah, masjid sebagai tempat pendidikan bagi masyarakat minoritas dan melalui masjid lahir pemikiran untuk mengembangkan bentuk pendidikan keagamaan yang permanen, seperti majelis taklim dan madrasah diniyah. Rekomendasi penelitian ini adalah perlu dibangun masjid di kecamatan yang tidak ada masjid dan penambahan masjid bagi kecamatan yang hanya satu masjid, minimal satu desa/kelurahan memiliki satu masjid. Masjid menjadi sentra pendidikan dan bentuk tanggung jawab negara yang memfasilitasi agar semua warga negara memperoleh layanan pendidikan agama. Hal ini merupakan wujud dari prinsip pendidikan sepanjang hayat (lifelong education).

\subsection{Dinamika Kerukunan Umat Beragama}

Secara umum, kondisi bangsa Indonesia aman, rukun, dan kondusif. Sejak merdeka pada tahun 1945, Indonesia telah dan terus membangun negeri, yang mengindikasikan adanya prasyarat suasana aman dan kondusif untuk pembangunan. Interaksi masyarakat (baca: umat beragama) pada umumnya berjalan baik dan kondusif, tercipta adanya suasana saling menghormati, toleransi, dan kerjasama antar-agama. Di Indonesia, banyak organisasi sosial lintas agama yang menunjukkan bentuk kerjasama antar-umat beragama yang sangat intens. Mereka bergerak bersama untuk kemanusiaan dengan tetap memegang keyakinannya masing-masing, misalnya dikenal slogan "ukhuwah terjalin, aqidah terjamin” (Ruhana, 2013).

Secara kasuistik tidak dapat dipungkiri adanya sejumlah kasus sosial yang bernuansa agama yang mengganggu kondisi kerukunan beragama dan ketentraman sosial. Sejumlah konflik etnorelijius (bernuansa etnis-keagamaan) telah pernah terjadi diIndonesia, terutama menjelang dan pascareformasi 1998, beberapa di antaranya: (a) pada tahun 1996 terjadi Peristiwa Situbondo dan 
KerusuhanTasikmalaya; (b) tahun 1997 terjadi kasus berlatar etnis-agama di Pekalongan, Temanggung, Banjarnegara, dan Sanggauledo; (c) tahun 1999 terjadi kerusuhan etnis di Sampit; dan (d) tahun 2006 - 2012 terjadi beberapa kasus terkait aliran Ahmadiyah dan terkait pendirian rumah ibadat. Kasus Ahmadiyah, terjadi di Bogor, Sukabumi, Serang, Cianjur, Bandung, dan Tasikmalaya. Sedangkan kasus pendirian rumah ibadat, seperti kasus pendirian Masjid di Batuplat, pendirian gereja Yasmin Bogor, dan Filadelfia Bekasi (Ruhana, 2013).

Kasus-kasus yang bersifat kasuistik-lokal di Indonesia telah memberi kesan negatif bahwa Indonesia tidak aman. Sebagaimana yang dituduhkan oleh Lembaga Swadaya Masyarakat (NGOs) pasca-sidang UPR di Jenewa 2012, bahwa Indonesia semakin tidak toleran dengan banyaknya kasus-kasus etnorelijius atau tindakan kekerasan tertentu. Pendapat tersebut keliru, karena memandang Indonesia yangluas hanya dari titik-titik rawan tertentu dan sangat tidak representatif. Padahal, kondisi objektif secara keseluruhan gambaran nasional Indonesia masih aman dan terkendali (Ruhana, 2013).

\section{METODE}

Penulis memperoleh dan mengumpulkan data dengan metode studi kepustakaan, yaitu mengumpulkan dan menguraikan bahan-bahan dari buku bacaan, jurnal, laporan penelitian Balitbangdiklat Kemenag RI, dan sumber dari internet. Objek kajian ini adalah sejarah dan pengertian perpustakaan masjid, peran perpustakaan masjid, dan bentuk inklusi sosial pada perpustakaan masjid.

\section{HASIL DAN PEMBAHASAN}

\subsection{Sejarah dan Pengertian Perpustakaan Masjid}

Sejarah peradaban dalam dunia Islam mencatat, bahwa perkembangan perpustakaan pernah mengalami masa kejayaan. Suwito \& Fauzan (2008) mencatat ada beberapa fase masa kejayaan perpustakaan Islam, antara lain:

1) Perpustakaan pada masa khalifah al-Makmun (tahun 813-833 Masehi). Pada saat itu didirikan Bait al-Hikmah. Lembaga ini menggabungkan perpustakaan, sanggar sastra, lembaga studi dan pusat observasi. Sebelum masa khalifah al-Makmun, Bait al-Hikmah telah dirintis oleh khalifah Harun al-Rasyid dan mencapai masa kejayaan intelektual pada masa khalifah al-Makmun.

2) Perpustakaan di Marv, Persia Timur. Pada masa ini sebagaimana ditulis oleh Yaqut dalam kamus geografinya menjelaskan bahwa di kota memiliki perpustakaan besar, di antaranya perpustakaan masjid dan perpustakaan madrasah. Tidak kurang dari 100.000 eksemplar buku menjadi koleksi perpustakaan.

3) Perpustakaan Madrasah Nizamiyah Baghdad. Perpustakaan ini memiliki koleksi sekitar 6.000 eksemplar buku. Pada waktu itu, perpustakaan Madrasah Nizamiyah menggunakan manajemen untuk mengelola perpustakaan sehingga koleksi perpustakaan tertata sesuai dengan klasifikasi dan memudahkan pengguna dalam mencari koleksi buku atau manuskrip.

4) Perpustakaan Dâr al-Hikmah di Kairo. Perpustakaan ini didirikan pada masa Dinasti Fathimiyah tahun 1004. Perpustakaan Dâr al-Hikmah merupakan pusat utama pendidikan tinggi di Mesir yang digunakan oleh para pelajar dan ilmuwan hampir selama satu abad lamanya.

5) Perpustakaan Universitas Cordova di Spanyol. Perpustakaan ini didirikan oleh Abdurrahman 
al-Nasyir dan memiliki koleksi ratusan ribu buku (menyaingi perpustakaan-perpustakaan yang berada di Daulat Abbasiyah).

6) Perpustakaan Khalifah Dinasti Fathimiyah kedua, yaitu di bawah kepemimpinan al-Aziz (975996). Koleksi pada perpustakaan ini sangat komplit dan beragam, seperti memiliki koleksi yang sangat terkenal yaitu kitab al-’Ayn, leksiograf (Jamhara) karya Ibn Durayd, koleksi ilmu alam, dan filsafat hellenistik berjumlah 18.000 eksemplar.

7) Perpustakaan Al Mutawakkil, Al Fath Ibn Khaqan (w.861), perpustakaan milik Ali bin Yahya yang diberi nama “Khizanatul Hikmah”, perpustakaan pribadi Jamaluddin al-Qifthi (w.64 H), perpustakaan pribadi Muwaffaq bin Muthran Dimasyqi yang memiliki koleksi sekitar 10.000 eksemplar, perpustakaan pribadi Adhud Al-Daula (w. 983) yang diberi nama "Khizanatul Kutub”. Perpustakaan ini berdiri dan dikelilingi oleh taman dan danau. Terdapat 360 ruangan untuk koleksi buku dan terdapat katalog untuk penelusuran koleksi perpustakaan.

8) Perpustakaan pribadi Ibn Sawwar, beliau memiliki perpustakaan Dar al-Ilm di Basroh dan di Ramhurmuz (sekitar Persia); perpustakaan pribadi Pangeran Dinasti Samaniyyah/Nuh (976977), yang memiliki koleksi perpustakaan sangat langka seperti koleksi filologi bahasa Arab, puisi, etika, dan sebagainya; perpustakaan pribadi Khazain al-Qusu di Kairo, yang memiliki koleksi mencapai 1,6 juta naskah dan terdapat 40 ruangan untuk menampung koleksi tersebut.

Adams (2003) menjelaskan bahwa "Three great libraries in Islam which held an important place in the cultural life of Muslims which were not only seen as store houses for books but seen as centers for learning and teaching were: The library of the Abbasid Caliphs in Baghdad (The House of Wisdom also known as Dar al-Hikma); the library of the Fatimide Caliphs in Cairo (The House of Science also known as Dar al-Ilm) and the library of the Ummayyad Caliphs in Spain (The Library of Cordova)". Perpustakaan-perpustakaan besar ini adalah tempat yang penting dalam kehidupan budaya Muslim. Perpustakaan telah menjadi pusat belajar dan mengajar. Perpustakaan Dar al - Hikma, memiliki koleksi literatur tentang astronomi dan memiliki sebuah observatorium astronomi. Perpustakaan ini terbuka untuk para akademisi dan masyarakat di seluruh dunia Islam. Perpustakaan Dar al - Ilm, memuat literatur berbagai bidang ilmu dan kaligrafi indah. Sementara itu, The Library of Cordoba merupakan perpustakaan terbesar di Spanyol pada masa kekhalifahan Islam saat itu.

Dalam kata pengantar Buku Pedoman Penyelenggaraan Perpustakaan Rumah Ibadah terbitan Perpustakaan Nasional (2011) disebutkan bahwa perpustakaan rumah ibadah dikategorikan sebagai perpustakaan khusus. Namun, perpustakaan rumah ibadah lebih tepat dimasukkan dalam kategori Perpustakaan Umum karena perpustakaan ini lebih terbuka bagi umat dan masyarakat umum disekitarnya tanpa membedakan umur, jenis kelamin, suku, ras, agama, dan status sosial-ekonomi. Keberadaan perpustakaan rumah ibadah di Indonesia cukup beragama, baik dari sisi misi, tujuan, sasaran, maupun lokasi. Sebagai contoh perpustakaan masjid atau mushola, perpustakaan gereja, perpustakaan vihara, dan perpustakaan klenteng.

Perpustakaan masjid menurut Djadjuliyanto (1992), tergolong perpustakaan umum yang berada di lingkungan masjid, dikelola oleh suatu badan di bawah pengawasan takmir masjid, serta salah satu sarana dan upaya untuk meningkatkan pengetahuan dan kegemaran membaca guna mencerdaskan kehidupan bangsa dan merupakan bagian integral dari kegiatan pembangunan umat Islam.

Sidi Gazalba (1994) yang dikutip Mustolehudin (2009) menjelaskan eksistensi masjid sebagai tempat penyediaan sumber-sumber informasi semakin menguat setelah Nabi Muhammad SAW wafat 
dan pada saat yang sama, persoalan-persoalan kehidupan terus berjalan. Ketika masalah-masalah baru terus bermunculan sementara Al-Qur'an dan hadits tidak memberikan solusi pemecahannya, maka ahli-ahli Islam atau para ulama menjawabnya dengan ijtihad. Dalam situasi demikian, hasil ijtihad dan seluruh literatur mengenai agama Islam, secara langsung atau tidak langsung membentuk kepustakaan Islam. Lebih jauh ia menjelaskan bahwa kepustakaan atau literatur Islam merupakan sumber ajaran, pendidikan, pengajaran, dan dakwah Islam yang ditempatkandi masjid.

Pada tahun 2007 pemerintah mengeluarkan sebuah undang-undang yang khusus mengatur tentang perpustakaan, yaitu Undang-Undang RI Nomor 43 Tahun 2007 tentang Perpustakaan. Pada pasal 22 ayat 4 dinyatakan bahwa masyarakat dapat menyelenggarakan perpustakaan umum untuk memfasilitasi terwujudnya pembelajaran masyarakat sepanjang hayat. Selanjutnya pada pasal 48 ayat 4 dijelaskan bahwa pembudayaan kegemaran membaca pada masyarakat dilakukan melalui penyediaan sarana perpustakaan di tempat-tempat umum yang mudah dijangkau. Melalui undang-undang ini, masyarakat diharapkan dapat berperan aktif dalam proses pembelajaran, diantaranya dengan mendirikan perpustakaan. Undang-undang ini dapat menjadi payung hukum dalam mendirikan perpustakaan masjid dalam rangka memfasilitasi masyarakat agar dapat mewujudkan masyarakat yang well educated atau terpelajar melalui pendidikan sepanjang hayat (Puslitbang Lektur Keagamaan, 2009).

Selain UU RI Nomor 43 Tahun 2007 tentang Perpustakaan, pada dekade 1990-an Dewan Masjid Indonesia (DMI) telah membentuk Badan Pembina Perpustakaan Masjid Indonesia (BPPMI) sebagai usaha pengembangan fungsi masjidyang tidak hanya sebagai rumah ibadah, tetapi juga sebagai lembaga sosial keagamaan. Karena itu, keberadaan masjid diharapkan dapat menjadi sentral budaya umat Islam. Terkait dengan hal ini, pada tanggal 25 Februari 1991 Menteri Agama RI mengukuhkan BPPMI melalui SK Dewan Masjid Indonesia (DMI) Nomor: 06/DMI/PP/KPTS/II/1991 sebagai bagian dari usaha penguatan peran masjid bagi pusat pembelajaran umat.

Dalam pedoman kerja BPPMI, perpustakaan masjid dibentuk sampai tingkat kecamatan di seluruh tanah air. Hal tersebut diperkuat oleh Presiden RI pada acara Pembukaan MTQ Nasional XVI di Yogyakarta tahun 1991. Presiden menyatakan pentingnya pembangunan dan pengembangan perpustakaan masjid dalam membangun dan mencerdaskan kehidupan bangsa, khususnya masyarakat muslim Indonesia (Puslitbang Lektur Keagamaan, 2009). Dirjen Bimas Islam Departemen Agama RI (sekarang Kemenag) Umar (2009) yang dikutip oleh Mustolehudin (2009) padaWorkshop Perpustakaan Masjid di Yogyakarta pada tanggal 21-24 Juli 2009, menyatakan bahwa perpustakaan masjid mempunyai peran strategis dalam khazanah penyelamatan dan pelestarian naskah-naskah Islam Nusantara yang berada di masjid. Pernyataan tersebut memunculkan pembangunan perpustakaan masjid di berbagai daerah di Indonesia. Munculnya berbagai perpustakaan masjid ini mendapat respon yang baik dari pemerintah dan masyarakat, terlihat dari banyaknya sumbangan dan bantuan buku, sarana dan prasarana perpustakaan, serta penyediaan dan pelatihan tenaga pengelola perpustakaan (Puslitbang Lektur Keagamaan, 2009).

\subsection{Peran Perpustakaan Masjid}

Kamarudin, dkk. (2014) menyatakan "the existence of mosque library is an approach to encourage society in inculcates the reading habit besides claiming the functions of the mosque library is only for performing the religious worship. Moreover, with the establishment of the mosque library in the mosque building itself, it can lead to the knowledgeable 
society. Besides, be able to expand the Islamic knowledge throughout the society either for Muslim, non-Muslim or new Muslim. The built of the mosque library is to ensure that all Muslim aware the existence of this library, which can give the information regards the ethics and Islamic resources". Dari pernyataan tersebut, terlihat bahwa perpustakaan masjid dapat mendorong masyarakat memiliki kebiasaan membaca dan masjid bukan semata-mata tempat ibadah. Melalui perpustakaan masjid, masyarakat menjadi berpengetahuan, baik bagi muslim, non- muslim, maupun muallaf (seseorang yang baru masuk islam). Melalui perpustakaan masjid, masyarakat menjadi lebih sadar dan peduli terhadap keberadaan perpustakaan masjid. Laugu (2007) menjelaskan bahwa perpustakaan masjid memiliki berbagai andil dalam perkembangan masyarakat Islam se-antero dunia. Perpustakaan masjid sebagai pusat aktivitas masyarakat memiliki peran, sebagai berikut.

\section{1) Peran Sosial}

Selama ini masjid dipakai tidak saja untuk kegiatan ibadah, tetapi menjadi pusat aneka ragam aktivitas sosial kemasyarakatan. Masjid tidak hanya menjadi tempat favorit untuk mengadakan suatu upacara atau perayaan, seperti perayaan Idul Fitri, Idul Adha, tahun baru Islam, pernikahan atau perceraian, dan kematian, tetapi juga juga digunakan sebagai pelayanan kesehatan, seperti klinik pengobatan dan apotek. Ketika terjadi bencana alam yang menimpa masyarakat, masjid digunakan sebagai tempat berlindung. Sebagai contoh, masjid Raya Baiturrahman Banda Aceh menjadi tempat pengungsian dan tempat berlindung bagi masyarakat yang terkena bencana Tsunami.

Kamarudin dkk (2014) menyatakan, "moreover, the mosque library can be used as discussion, consultation, research, exhibitions, campaigns and others in order to strengthen the friendships among the society such as parents, children, teens, adult and elderly people irrespective of the age, race, ethnics, and profession. Besides, as Islamic preaching dissemination, with the various collection of knowledge including the Islamic resources, it is accessible for the communities to refer to, and do a research". Pernyataan tersebut menjelaskan bahwa perpustakaan masjid dapat digunakan sebagai tempat diskusi, konsultasi, penelitian, pameran, kampanye, dan lain-lain yang dapat memperkuat silaturahim di masyarakat. Selain itu, sebagai penyebaran Islam, dengan berbagai koleksi pengetahuan yang memuat sumber-sumber Islam yang dapat diakses oleh masyarakat sebagai tempat rujukan dan melakukan penelitian.

Berdasarkan data laporan penelitian Balitbangdiklat Kemenag pada tahun 2005-2008, telah dilakukan peningkatan sarana dan prasarana peribadatan antara lain, dengan memberikan bantuan untuk pembangunan dan rehabilitasi tempat peribadatan guna mendorong peran aktif masyarakat dalam memenuhi kebutuhan tempat peribadatan secara swadaya. Pada tahun 2005 dan 2006 telah diberikan bantuan untuk rehabilitasi tempat ibadat masing-masing sebanyak 1.891 buah dan772 buah (Tabel 1). Tahun 2007 dan 2008 kebijakan pemberian bantuan untuk tempat ibadat mengalami perubahan dari kebijakan rehabilitasi menjadi bantuan pembangunan tempat ibadat, mengingat pada tahun-tahun tersebut banyak rumah ibadat yang hancur dan roboh akibat terjadinya bencana alam di tanah air. Pada tahun 2007, dilaksanakan pemberian bantuan pembangunan tempat peribadatan, yang terdiri atas masjid 125 unit, gereja kristen di 61 lokasi, gereja katolik di 38 lokasi, dan pura 76 unit. pemberian bantuan sarana dan prasarana untuk masjid di 205 
lokasi, gereja kristen di 47 lokasi, gereja katolik sebanyak 78 unit, pura di 95 lokasi, dan wihara di 5 lokasi. Pada tahun 2008 disediakan dana untuk pemberian bantuan pembangunan tempat peribadatan, yang terdiri atas masjid 596 unit, gereja kristen 101 paket, gereja katolik 51 unit, pura 25 unit, dan wihara 20 unit. Pemberian bantuan sarana dan prasarana untuk masjid di 105 lokasi, gereja kristen di 68 lokasi, gereja katolik sebanyak 48 unit, pura di 995 lokasi, dan wihara di 10 lokasi.

Tabel 1. Rehabilitasi dan Pembangunan Tempat Ibadah Tahun 2005—2008

\begin{tabular}{|l|c|c|c|c|}
\hline Tempat Ibadat & $\mathbf{2 0 0 5}$ & $\mathbf{2 0 0 6}$ & $\mathbf{2 0 0 7}$ & $\mathbf{2 0 0 8}$ \\
\hline Masjid & 1.748 & 498 & 125 & 596 \\
Gereja Kristen & 49 & 199 & 61 & 101 \\
Gereja Katolik & 38 & 30 & 38 & 51 \\
Pura & 30 & 34 & 76 & 25 \\
Vihara & 26 & 11 & - & 20 \\
\hline Jumlah & 1.891 & 772 & 300 & 793 \\
\hline
\end{tabular}

Sumber: Laporan Penelitian Peningkatan Kualitas Kehidupan Beragama

(Puslitbang Kehidupan Keagamaan Balitbangdiklat Kemenag 2008)

Potensi masjid sangat besar terutama dalam memainkan perannya sebagai lembaga sosial keagamaan dan lembaga pendidikan keagamaan yang bertujuan untuk memberdayakan dan menunjang peningkatan kesejahteraan masyarakat, mengurangi dampak negatif ekstrimisme masyarakat, serta memberikan pelayanan pendidikan dan pengembangan sumber daya manusia, terutama bagi masyarakat pedesaan dan ekonomi lemah. Namun, demikian potensi masjid yang besar belum sepenuhnya bisa digarap. Langkah-langkah bersifat strategis dan menyeluruh perlu dilakukan agar masjid mampu menjadi jembatan bagi umat untuk bangkit memberdayakan dirinya sendiri dan berlangsung di setiap masjid. Solusi tersebut diharapkan mampu membawa pengaruh besar dalam upaya memakmurkan masjid.

\section{2) Peran Pendidikan}

Perpustakaan masjid merupakan tempat pembelajaran sepanjang masa bagi umat. Karya-karya ulama atau literatur ke-islaman dan koleksi lainnya akan memberikan kekayaan khazanah keilmuan bagi umat lslam. Masyarakat memperoleh pengetahuan karena masjid menyediakan sumber-sumber informasi yang beraneka ragam untuk mendukung proses pembelajaran. Koleksi yang dimiliki perpustakaan tidak hanya tentang keislaman, tetapi juga aneka bidang ilmu, seperti sosial, politik, kesehatan, seni dan sebagainya.

Kamarudin (2014) menyatakan bahwa "as a reference purpose, the mosque library has to subscribe the latest collections of the resources in order to aware the society with the update information. Moreover, as a recreational centre, the reading campaign promoted by the government should be taken into consideration. As pursue to the reading culture among society, the role of mosque library cannot simply justified. The mosque library should be seen as an important ways to encourage and inculcate the reading culture among society. The provision of the internet connection or wifi at the mosque library plays an important approach for the users to access the information. The mosque library with fully equipped with the technology will lead to 
the optimum utilization of the facilities". Pernyataan tersebut menjelaskan bahwa perpustakaan masjid menjadi tujuan referensi sehingga perlu memiliki koleksi terbaru agar informasinya selalu uptodate. Perpustakaan masjid juga sebagai pusat rekreasi dan tempat untuk membudayakan membaca bagi masyarakat. Perpustakaan masjid juga perlu menyediakan koneksi internet yang memadai agar masyarakat dapat mengakses informasi secara lancar.

Perpustakaan masjid menjadi bagian yang penting dalam menyokong masjid menjadi pusat perkembangan peradaban umat manusia. Dengan berfungsinya perpustakaan masjid, maka perannya semakin besar dalam mencerdaskan umat dan mewujudkan komunitas belajar (learning society). Masyarakat belajar, di antara cirinya sadar akan informasi dan cerdas dalam memilih informasi. Informasi tersebut bukan hanya informasi keagamaan ilmiah, tetapi juga informasi popular. Untuk itu, perpustakaan masjid perlu didukung oleh koleksi yang memadai, baik subjek maupun layanan pendukung lainnya.

\subsection{Bentuk Inklusi Sosial Pada Perpustakaan Masjid}

Sebagai perpustakaan umum, perpustakaan masjid memiliki aneka ragam pengguna dari berbagai latar belakang, termasuk mereka yang berasal dari kaum marjinal, mereka dengan strata sosial ekonomi lemah, mereka yang memiliki disabilitas, atau mereka dengan keyakinan minoritas. Perpustakaan masjid memiliki berbagai aktivitas yang berkaitan dan mencerminkan inklusi sosial terutama dalam pemberian layanan kepada penggunanya. Oleh karena itu, dalam rangka melaksanakan tugas pokok dan fungsinya, perpustakaan masjid perlu meningkatkan kinerjanya untuk memberikan pelayanan kepada penggunanya secara efektif dan efisien dengan membangun kesadaran inklusif, sebagai berikut.

1) Perpustakaan masjid, harus mampu mengakomodir kebutuhan informasi penggunanya. Untuk dapat memenuhi kebutuhan informasi pengguna, bidang subjek koleksi yang dimiliki perpustakaan masjid harus ditambah, artinya tidak hanya pada pengetahuan keislaman tetapi juga bidang ilmu lain, seperti sosial, politik, kesehatan, seni dan budaya. Dengan demikian, maka perpustakaan masjid menjadi bagian dari elemen bangsa yang turut serta mencerdaskan masyarakat. Peran edukasi yang dijalankan ini sudah sesuai dengan amanat yang ada dalam UUD negara ini dan bidang koleksi yang beragam tersebut, sangat memungkinkan bisa diakses oleh masyarakat luas tidak hanya masyarakat muslim. Kondisi tersebut, senada dengan hasil penelitian yang dilakukan oleh Puslitbang Lektur Keagamaan, Badan Litbang dan Diklat Kemenag mengenai “Literatur Islam pada Perpustakaan Masjid”. Penelitian ini dilakukan di delapan provinsi dengan 15 masjid raya, yaitu:

a) Perpustakaan Masjid Raya Baiturrahman Banda Aceh;

b) Perpustakaan Masjid Raya Taqwa Palembang;

c) Perpustakaan Masjid Agung Palembang;

d) Pusat Perpustakaan Islam Indonesia (PPII) Masjid Istiqlal, Jakarta;

e) Perpustakaan Jakarta Islamic Centre (JIC);

f) Perpustakaan Masjid Raya Bandung;

g) Perpustakaan Masjid Agung Al-Ukhuwah, Bandung;

h) Perpustakaan Masjid Kauman Yogyakarta;

i) Perpustakaan Masjid Syuhada Yogyakarta;

j) Perpustakaan Masjid Raya At-Taqwa Mataram; 
k) Perpustakaan Masjid Agung Al-Muttaqin, Mataram;

l) Perpustakaan Masjid Raya Makassar;

m) Perpustakaan Masjid Al-Markaz Al-Islami Jenderal M. Jusuf, Makassar;

n) Perpustakaan Masjid Raya Sabilal Muhtadin, Banjarmasin;

o) Perpustakaan Masjid Agung Miftahul Ihsan Kodya Banjarmasin.

Beberapa hasil penelitiannya menunjukkan bahwa: (1) koleksi literatur di perpustakaan masjid raya sangat beragam dan tidak hanya literatur Islam; (2) bidang kajian yang terdapat pada koleksi literatur pada perpustakaan masjid raya hampir meliputi seluruh bidang kajian, dari koleksi keislaman hingga koleksi umum, seperti buku-buku sains-teknologi, ekonomi, sosial-budaya, politik, manajemen, dan lain-lain. Demikian juga dengan buku-buku keislamannya, seperti ensiklopedia, kumpulan karya, bunga rampai, dan lain-lain hingga koleksi khusus seperti Al-Qur'an dan Ilmu Al-Qur'an, Hadis dan Ulumul hadis, Akidah dan Ilmu Kalam, Fiqih dan Hukum Islam, Akhlak dan Tasawuf, Sejarah/ Tarikh Islam, dan Biografi; (3) peta literatur Islam koleksi perpustakaan masjid yang terdata dan sudah terolah adalah sebanyak 29.529 judul buku dengan sebaran sebagai berikut: Islam Umum (11,13\%); Al-Qur'an dan Ilmu yang berkaitan (9,83\%); Hadis dan Ilmuyang Berkaitan (8,66\%); Aqaid dan Ilmu Kalam (11.32\%); Fikih (18,67\%); Akhlak Tasawuf (11,30\%); Sosial dan Budaya (9,21\%); Filsafat dan Perkembangan (8,09\%); Aliran dan Sekte (1,76\%); dan Sejarah Islam dan Biografi (10,03\%).

Pemetaan sebagaimana tersebut di atas menyatakan bahwa koleksi buku tema fikih menempati proporsi terbesar $(18,67 \%)$ dibanding koleksi lainnya. Hal tersebut cukup fungsional dengan kebutuhan membaca pengunjung perpustakaan yang pada umumnya memang membutuhkan buku tema Fikih seputar kehidupan sehari-hari mereka, seperti: masalah ibadah, do’a-do'a, muamalah, hukum perkawinan (munahakat), hukum waris (faraid) dan wasiat, hukum pidana Islam (jinayat), hukum peradilan (Qada'), Ekonomi Islam, Pendidikan Islam, dan lain-lain.

2) Perpustakaan masjid harus menjadi ruang terbuka bagi aktivitas sosial kemasyarakatan. Hal ini penting karena para penggunanya berasal dari berbagai latar belakang yang berbeda dan harus mendapatkan pelayanan yang sama tanpa harus melihat perbedaan yang ada, seperti perbedaan agama, kepercayaan, suku, ras, fisik dan sebagainya. Termasuk di dalamnya adalah kelompok minoritas juga harus mendapat pelayanan yang sama, karena perpustakaan menjadi media untuk diskusi masalah sosial dan berbagi pengetahuan, sebagai langkah untuk mewujudkan kerukunan antar umat beragama.

3) Perpustakaan masjid harus menjadi media pembelajaran sepanjang hayat (lifelong education). Kondisi ini memang perlu dibangun sehingga perpustakaan masjid turut memberikan kesempatan bagi mereka yang memiliki disabilitas untuk mendapatkan pelayanan dan kesempatan yang sama dalam mendapatkan pengetahuan, misalnya melalui koleksi kitab suci aksara braile. Data pada Kementerian Agama menyebutkan bahwa dalam upaya meningkatkan kadar keimanan dan ketaqwaan serta memperluas wawasan keagamaan umat beragama, Pemerintah ikut membantu masyarakat dalam memenuhi kebutuhan penyediaan kitab suci berbagai agama (Islam, Kristen, Katolik, Hindu, dan Buddha) termasuk terjemahan dan tafsirnya serta buku-buku keagamaan lainnya. Kegiatan ini diharapkan pula akan mendorong para ahli untuk mengembangkan penafsiran kitab suci sesuai dengan perkembangan zaman serta tuntutan pembangunan. Pada tahun 2006 telah dilaksanakan pengadaan kitab suci sebanyak 75.573 eksemplar, sedangkan pada tahun 2007 pengadaan kitab suci dapat dirinci sebagai berikut: kitab suci agama Islam 2.883 eksemplar, kitab suci agama Katolik 
2.848 eksemplar, kitab suci agama Kristen 18.838 eksemplar, kitab suci agama Hindu 12.100 eksemplar, dan kitab suci agama Buddha 1 paket. Pada tahun 2008 disediakan dana pengadaan kitab suci yang terdiri atas: kitab suci agama Islam 198.118 eksemplar, kitab suci agama Katolik 2.525 eksemplar, kitab suci agama Kristen 886 eksemplar, kitab suci agama Hindu 23.350 eksemplar, dan kitab suci agama Buddha 10.000 eksemplar.

4) Perpustakaan masjid harus menjadi pusat pelayanan dan pemahaman keagamaan. Oleh karena itu, peran yang harus diambil oleh perpustakaan masjid ialah melakukan peningkatan kualitas pelayanan dan pemahaman agama serta kehidupan beragama melalui penyediaan koleksi perpustakaan yang dapat meningkatkan kualitas materi dan tenaga penyuluh agama dan pelayanan keagamaan, terutama yang bertugas di daerah rawan konflik, daerah terpencil, dan daerah terkena musibah. Kondisi ini diperkuat oleh hasil penelitian yang dilakukan oleh Puslitbang Pendidikan Agama dan Keagamaan Kemenag pada tahun 2006 mengenai pelayanan pendidikan keagamaan, khususnya bagi umat Islam sebagai kaum minoritas di beberapa wilayah di Indonesia. Hasil penelitiannya, menyatakan: (1) masjid menjadi tempat pertama dan utama dalam pelayanan keagamaan; dan (2) pendidikan yang diprakarsai oleh masyarakat, seperti majelis taklim dan madrasah diniyah sangat berkembang sehingga dapat terus dibina melalui masjid dan prasarana pendukung, seperti perpustakaan masjid.

5) Perpustakaan masjid harus mampu mewujudkan masyarakat yang informed. Dalam hal ini, masyarakat yang mempunyai pengetahuan yang baik sehingga mampu mengambil keputusan, mampu memanfaatkan akses terhadap pelayanan umum, menggunakan hak-haknya, dan membuat pemerintah dan pihak-pihak lain yang terlibat bersikap akuntabel atas kebijakan dan tindakan yang mempengaruhi kehidupan masyarakat. Masyarakat yang informed, lebih mampu memenuhi kebutuhannya sendiri.

6) Perpustakaan masjid harus mampu memberikan manfaat bagi masyarakat dari ilmu pengetahuan dan teknologi, seni dan budaya, demi kesejahteraan umat manusia. Hal ini sejalan dengan Piagam Hak Asasi Manusia tentang Hak Atas Kebebasan Informasi, yakni setiap orang berhak untuk berkomunikasi dan memperoleh informasi untuk mengembangkan pribadi dan lingkungan sosialnya, serta setiap orang berhak untuk mencari, memperoleh, memiliki, menyimpan, mengolah, dan menyampaikan informasi dengan menggunakan segala jenis saluran yang tersedia.

7) Perpustakaan masjid harus menjadi lumbung khasanah pemikiran dan kebudayaan. Hal ini merupakan salah satu langkah penting untuk membangun kesadaran inklusif di perpustakaan. Kesadaran inklusif di perpustakaan tidak hanya sekedar teknik-teknik pelaksanaan perpustakaan, seperti teknik pengatalogan, teknik klasifikasi, dan teknik peminjaman dan manajemen sumber daya informasi yang telah dipakai secara umum, tetapi menjadi salah satu upaya untuk mengenalkan dan menyebarkan himpunan rekaman-rekaman pemikiran manusia demi kelanjutan proses belajar seluruh anggota masyarakat dan sebagai salah satu cara memajukan dunia yang demokratis.

8) Perpustakaan masjid harus menjadi bagian dari kegiatan pemberdayaan masyarakat. Hal ini sangat penting agar akses informasi pada perpustakan masjid tersebut tidak tersumbat antara masyarakat dengan masyarakat lain dan antara masyarakat dengan pemerintah. Informasi tersebut meliputi ilmu pengetahuan, program dan kinerja pemerintah, hak dan kewajiban dalam bermasyarakat dan tentang pelayanan umum. Penelitian berkenaan dengan pemberdayaan peran masjid pernah dilakukan oleh Anik Farida (2014) dengan judul "Efektivitas Manajemen 
Masjid dalam Pemberdayaan Umat”. Penelitian dilakukan di wilayah Bandung dengan mengambil dua lokasi, yaitu Masjid Mujahidin yang terletak di Jalan Sancang Bandung dan Masjid Salman Kampus ITB Bandung. Masjid Mujahidin dipilih sebagai model masjid yang menerapkan manajemen modern dalam rangka pemberdayaan ekonomi umat. Salah satu program unggulan masjid ini adalah pemberdayaan ekonomi umat berupa pemberian modal usaha kepada beberapa fakir miskin. Masjid Salman Kampus ITB Bandung dipilih sebagai model masjid yang menerapkan manajemen modern dalam upaya memberdayakan umat pada bidang keilmuan, yakni dengan menjadikan Masjid Salman sebagai pusat kegiatan belajar mengajar dan program keilmuwan, baik ilmu agama maupun ilmu umum. Program ini dapat menjangkau hampir semua jenjang pendidikan masyarakat.

Pada penelitian tersebut ditemukan varian fungsi sosial dari Masjid Salman Kampus ITB. Fungsi sosial yang dilaksanakan Masjid Salman didesain dalam format pendidikan dan pemberdayaan ekonomi. Beberapa divisi yang secara khusus menjalankan fungsi pemberdayaan pendidikan atau keilmuan dan juga pemberdayaan ekonomi. Bidang Pengkajian dan Penerbitan (BPP)YPM Salman ITB merupakan peleburan dari 3 lembaga, yaitu Lembaga Pengkajian Islam (LPI), Lembaga Pengembangan Ekonomi Syariah (LPES), dan Lembaga Penerbitan Salman (LPS). Didirikan pada tahun 2010, bidang ini mengkhususkan diri melakukan kajian Islam kontemporer yang sesuai dengan kebutuhan masyarakat saat ini. Kajian tersebut berupa kajian tafsir al-Quran, literasi, dan budaya. BPP Salman ITB juga membawahi Salman Media. Sub divisi ini bertanggung jawab terhadap pengembangan berbagai media di Salman ITB. Dua di antaranya yang telah konsisten berjalan adalah SalmanITB.com, buletin Misykat, dan buletin Salman News. Selain lembagalembaga di atas, terdapat Karisma Learning Center (KLC) yang merupakan pusat bimbingan belajar siswa SMP dan SMA di Masjid Salman ITB dan berada di bawah naungan Karisma ITB.

Pada kegiatan Pemberdayaan Masyarakat, Masjid Salman ITB juga melaksanakan Program Ganesha Madani yang bertujuan memandirikan masyarakat di sekitar Salman ITB. Terdapat 4 pilar utama yang menjadi perhatian pokok, yaitu Pilar Kesehatan, Pilar Pendidikan, Pilar Lingkungan, dan Pilar Ekonomi. Program dari Pilar Kesehatan diberi nama Ganesha Sehat. Dalam program ini ada Pelayanan Kesehatan, Pendidikan Kesehatan, Parenting Class, dan Pendampingan Kebersihan PKL. Menariknya, selain membangun kesadaran masyarakat dalam hal memerhatikan kesehatan diri, keluarga dan lingkungan, lewat Ganesha Sehat masyarakat juga dapat mengetahui proses pembuatan Kompos Organik. Kegiatan ini dikemas dalam bentuk penyuluhan di Program Pendampingan Kebersihan PKL. Secara garis besar peserta diajarkan memisahkan sampah organik dan anorganik. Sampah anorganik nantinya didaur ulang, sedangkan sampah organik yang terkumpul diolah kembali menjadi Kompos Organik. Harapannya, kegiatan ini bisa bernilai ekonomi bagi masyarakat.

Pada Pilar Pendidikan, terdapat program Ganesha Mengkaji. Program ini bertujuan memberikan bantuan tenaga pengajar ke DKM-DKM di Lingkungan Ganesha, baik tenaga pendidik agama maupun umum. Ke depannya, tim Ganesha mengkaji bercita-cita ingin mendirikan perpustakaan kecil di masjid-masjid di 4 RW sekitar Ganesha. Pada Bidang Lingkungan, Ganesha Madani mempersembahkan program Salman Hejo. Di dalamnya ada Program Teknologi Lingkungan Tepat Guna. Dalam program ini tim bersama-sama masyarakat menjalankan kegiatan Riset Persampahan Salman, Riset Ekonomis Produk Pengelolaan Sampah, Instalasi Daur Ulang Air Wudhu, Cikapundung Bersih, dan Salman Goes to Green (Rumah Kompos dan Rumah Hijau).

Adapun Pilar Ekonomi, yang diberi nama Ganesha Berkah. Saat ini, Tim Ganesha Berkah 
sedang merencanakan Program Permodalan Bergilir PKL sehingga para PKL selain mendapat pengetahuan tentang pengolahan sampah organik menjadi kompos, juga mendapatkan modal secara bergilir pada waktu yang telah ditetapkan.

\section{KESIMPULAN}

Perpustakaan masjid dapat dikatakan sebagai bagian dari upaya membangun kesadaran inklusi dan melakukan pemberdayaan masyarakat, baik dalam kehidupan beragama maupun bermasyarakat. Problem-problem antarumat beragama dapat secara mandiri ditangani dan diselesaikan diantara mereka. Pemberdayaan masyarakat dapat dilakukan dengan memberikan fasilitas, edukasi, dan akomodasi terkait berbagai kebutuhan masyarakat, tanpa membeda-bedakan masyarakat penggunanya, baik dari segi agama, keyakinan, golongan, maupun fisik. Perpustakaan masjid merupakan perwujudan demokrasi dan sarana menuju masyarakat well informed. Perpustakaan masjid memiliki berbagai aktivitas sosial keagamaan yang mencerminkan inklusi sosial, terutama dalam pemberian layanan kepada penggunanya. Perpustakaan masjid harus mampu mengakomodir kebutuhan informasi penggunanya, menjadi ruang terbuka bagi aktivitas sosial kemasyarakatan, menjadi media pembelajaran sepanjang hayat atau lifelong education, mampu mewujudkan masyarakat yang informed, mampu memberikan ilmu pengetahuan dan teknologi, seni dan budayayang bermanfaat bagi masyarakat,menjadi lumbung khasanah pemikiran dan kebudayaan, serta menjadi bagian dari kegiatan pemberdayaan masyarakat. Inklusi sosial adalah upaya menempatkan martabat dan kemandirian individu sebagai modal utama untuk mencapai kualitas hidup yang ideal. Melalui inklusi sosial, seluruh elemen masyarakat mendapat perlakuan yang setara dan memperoleh kesempatan yang sama sebagai warga negara, terlepas dari perbedaan apapun. Dengan hadirnya perpustakaan masjid di masyarakat, diharapkan tidak ada lagi seorangpun yang mengalami diskriminasi, intoleransi, intimidasi, penindasan, pengucilan, kekerasan, penyiksaan, dan perlakuan yang tidak adil.

\section{UCAPAN TERIMAKASIH}

Terima kasih penulis sampaikan kepada Tim Peneliti Balitbangdiklat Kemenag atas dukungan yang diberikan dalam penyusunan naskah ini.

\section{DAFTAR PUSTAKA}

Adams, Roldah. 2003. "Historical Development of Islamic Libraries Internationally and in South Africa: a Case Study of the Islamic Library in Gatesville. Minithesis. Department of Library and Information Science, University of the Western Cape. (http://works.bepress.com/rolda h_adams/1, diakses 12 Oktober 2015).

An Nahlawi, Abdurrahman. 1995. Pendidikan Islam di Rumah, Sekolah, dan Masyarakat. Jakarta: Gema Insani Press.

Badan Litbang dan Diklat Kementerian Agama. 2008. “Peningkatan Kualitas Kehidupan Beragama”. Laporan Penelitian Puslitbang Kehidupan Keagamaan. Jakarta.

Djadjuliyanto. 1992. Pedoman Penyelenggaraan dan Penyusunan Tajuk Subyek untuk Perpustakaan. Jakarta: Muara Agung.

Farida, Anik. 2014. "Islamisasi Sains dan Saintifikasi Islam: Model Manajemen Pemberdayaan di Masjid Salman ITB Bandung”. HARMONI Jurnal Multikultural \& Multireligius, Vol. 13 No. 1 Januari - April 2014: 38-53.

Kamarudin, Nurfaizah, Mohsinin Mohsin, dan Nurul Huda Izzati Jamil. 2014. "Mosque Library: Roles and Issues”. A Conceptual Paper at Konferensi Antarbangsa Islam Borneo, 10-11 September 2014. (http://versys.uitm.edu.my/prisma/view/viewPdf.php?pid=44881, diakses 11 Oktober 2015).

Kamus Collins English Dictionary. (http://www.collinsdictionary.com/dictionary/english/social-inclu- 
sion, diakses 6 Desember 2015).

Kamus Merriam-Webster. (http://www.merriam-webster.com/dictionary/inclusive, diakses 6 Desember 2015).

Laugu, Nurdin. 2006. "Peran Sosial dan Keagamaan Perpustakaan Masjid dalam Perspektif Sejarah”. Fihris, Vo.1, No. 2, Juli - Desember 2006.

Laugu, Nurdin. 2007. "The Roles of Mosque Libraries Through History”. Al-Jami 'ah, Vol. 45, No. 1, $2007 \mathrm{M} / 1428 \mathrm{H}$.

Mustolehudin. 2009. “Pengelolaan Perpustakaan Masjid di Era Globalisasi Informasi”. Jurnal Analisa, Vol. XVI, No.02, Juli - Desember 2009.

Perpustakaan Nasional. 2011. Buku Pedoman Penyelenggaraan Perpustakaan Rumah Ibadah. Jakarta: Perpustakaan Nasional.

Puslitbang Lektur dan Khazanah Keagamaan Badan Litbang dan Diklat Kementerian Agama. 2009. Literatur Islam pada Perpustakaan Masjid. Jakarta.

Puslitbang Pendidikan Agama dan Keagamaan Badan Litbang dan Diklat Kementerian Agama. 2006. "Studi Pelayanan Pendidikan Keagamaan pada Masyarakat Minoritas". Kumpulan Sinopsis HasilHasil Penelitian Pendidikan Agama dan Keagamaan. Jakarta.

Roscommon Country Council. "Introduction to Social Inclusion". (http://www.roscommoncoco.ie/en/ Services/Comm Ent/Social Inclusion Unit/Introduction to Social_Inclusion/, diakses 6 Desember 2015).

Ruhana, Akmal Salim. 2013. "Peranan Belia dalam Menjaga Kerukunan Antarumat Beragama: Pengalaman Indonesia”. Kertas kerja dipresentasikan dalam "Program Konvensyen Pendakwah Muda Institusi Pengajian Tinggi ASEAN 2013,” di Universiti Sains Islam Malaysia (USIM), Negeri Sembilan, Malaysia, pada 3 Februari 2013.

Suwito dan Fauzan. 2005. Sejarah Sosial Pendidikan Islam. Jakarta: Penada Media.

Undang - Undang Dasar Negara RI Tahun 1945. Jakarta.

Undang - Undang RI No. 43 Tahun 2007 tentang Perpustakan. Jakarta.

Yayasan Daya Akselerasi Aditama. 2013. "Pengertian Inklusi”. (https://daksablog.wordpress.com/2013/ 05/10/pengertian-inklusi/, diakses 6 Desember 2015).

Zuhdi, Muhammad. 2010. "Peran Perpustakaan Masjid dalam Mencerdaskan Ummat”. Al-Maktabah Jurnal Komunikasi dan Informasi Perpustakaan, Vol.10, No.1, Juli 2010: 83-96. 